\title{
PHYSICAL HABITAT ASSESSMENT OF A REMAINING HIGH- BIODIVERSITY REACH OF THE UPPER YANGTZE RIVER, CHINA
}

\author{
ZHANG, H. $^{1}-$ WANG, C.Y. ${ }^{1}-$ WU, J.M. ${ }^{1}-$ DU, H. ${ }^{1}-$ WEI, Q.W. $.^{{ }^{*}}-$ KANG, M. ${ }^{2^{*}}$ \\ ${ }^{1}$ Key Laboratory of Freshwater Biodiversity Conservation, Ministry of Agriculture of China, \\ Yangtze River Fisheries Research Institute, Chinese Academy of Fishery Sciences \\ No.8, 1 st Wudayuan Road, Donghu Hi-Tech Development Zone, Wuhan, Hubei Province, \\ 430223, P. R. China \\ (phone: +86-27-8178-0118; fax: +86-27-8178-0118) \\ ${ }^{2}$ Department of Maritime Police and Production System / The Institute of Marine Industry, \\ Gyeongsang National University \\ Cheondaegukchi-Gil 38, Tongyeong-si, Gyeongsangnam-do, 650-160, South Korea \\ (phone: +82-55-772-9187; fax: +82-55-772-9189) \\ ${ }^{*}$ Corresponding author \\ e-mail:weiqw@yfi.ac.cn;mk@gnu.ac.kr \\ (Received $10^{\text {th }}$ Aug 2015; accepted $14^{\text {th }}$ Nov 2015)
}

\begin{abstract}
A scientific assessment on the physical habitat of a river in the only remaining free-flowing stretch in the Upper Yangtze, which has one of the world's highest fish diversity and is critically important. A field survey was tentatively conducted in this non-wadeable and data-limited reach $(392 \mathrm{~km}$ river length, its $98.3 \%$ included the national protected area) of the Upper Yangtze River using a $200 \mathrm{kHz}$ echosounder and a $600 \mathrm{kHz}$ Acoustic Doppler Current Profiler in 2011. The water depth, acoustic backscatter characteristics of river bottom (hardness and roughness), and flowing characteristics (depthaveraged velocity (DAV), Froude number (Fr), and Reynolds number (Re)), which are popular in describing the habitat preference of aquatic organisms, were determined to describe the river habitat properties. The K-means clustering method using parameters river thalweg depth, DAV, and Fr categorized the 392 river segments into three biological meaningful habitat types, pool, run and riffle, with occupied $5.4 \%, 30.1 \%$ and $64.5 \%$, respectively. Thus, the pool was the most comparatively rare habitat type and should be carefully protected. This study provides a fast and efficient method for assessing the habitat characteristics of a non-wadeable and data-limited river, moreover, the results supply fundamental information for better national protected reach management.
\end{abstract}

Keywords: river habitat survey, echosounder, $A D C P$, river management, protected area.

\section{Introduction}

A river environment comprises the habitat for flora and fauna; it is spatially and temporally dynamic, and its condition and characteristics provide the basis for its health assessment (Allan and Castillo, 2007; Hauer and Lamberti, 2007; Harding et al., 2009). Describing the physical habitat is a central component of the assessment, management, and improvement of river environments (Clifford et al., 2006). The physical habitat factors such as water depth, bottom type and flowing characteristics, tend to be highly correlated with the life of aquatic organisms, and are also critical for river management (Frissell et al., 1986; Hawkins et al., 1993).

The Yangtze River (Changjiang) is noted for high fish diversity with more than 361 species (Fu et al., 2003). The upper reach of the river is a dominant area supporting this diversity. The Upper Yangtze is also a rich hydropower resource (up to $1.21 \times 10^{9}$ 
$\mathrm{kW}$ ), constituting the largest hydropower energy base in China (Yang et al., 2007). Thus, further development of hydroelectric dams in the Upper Yangtze is realistically inevitable. At present, about 27 dams have been constructed or planned in the Jinsha River, a stretch of the Upper Yangtze main stream, and two have been built in the Chuanjiang River, a segment of the Yangtze main stream downstream from the Jinsha (Yang et al., 2007). In the future, very few free-flowing stretches will remain in the only 3,330 $\mathrm{km}$ of the Upper Yangtze River because of the above dam issue ( $\mathrm{Yu}$ and $\mathrm{Lu}$, 2005). To compensate for the adverse effects of dam construction, a nature preservation area, the Upper Yangtze National Reserve, was created in a free-flowing stretch from Xiangjiaba Dam, the most downstream dam of the Jinsha River, to Chongqing city at the tail end of the Three Gorges Reservoir (Fan et al., 2006). This protected area was intended to preserve three internationally protected fish species, Chinese paddlefish Psephurus gladius (Martens 1862), Dabry's sturgeon Acipenser dabryanus (Duméril 1869), and the Dianchi Bullhead Pseudobagrus medianalis (Regan 1904), as well as 67 endemic fishes along with their remaining habitat (Fan et al., 2006; Zhang et al., 2009, 2011).

The environment of the Yangtze River has been of concern for many years ( $\mathrm{Yu}$ and Lu, 2005). Recent research has included studies on water quality (Müller et al., 2008), flow velocity (Chen et al., 2007, Zhang et al., 2008), flow discharge (Wang et al., 2008), and channel morphology (Li et al., 2007). However, nearly all studies were focused on the river reaches below the Three Gorges Dam or a little upstream site, Chongqing city. Moreover, the key elements of these studies were erosion and sedimentation processes of the river channel, river-lake relationships, and/or flood control. They were not considered with aquatic organisms or the biological aspects of the river environment, therefore they were not directly in support of the river micro or mesoscale biodiversity management.

There are some issues which have made it difficult for scientists to resolve. 1) The Yangtze River is a very extensive river, and there has been much exploitation of the water supply, navigation, hydroelectricity and others. The fish and fishery were the last aspects to be considered. 2) The expansive size of the Yangtze River induces limitations on implementing the standard sampling and assessment methods which were commonly used in streams or in wadeable rivers (Bain and Stevenson, 1999; Harding et al., 2009) and were not applicable in the Yangtze River. Also, the expenditure will be significant when the entire river needs to be intensively surveyed. 3) The limitations of survey instruments were a shortcoming in the past. Undoubtedly, a scientific assessment of the environment for the free-flowing reach comprising of the Upper Yangtze National Reserve is critically important and urgently requires conducting. Even though this reach has been designated as a protected reach, most of the river channels still experience heavy anthropogenic uses for waterway regulation and sand/gravel extraction, which will alter the river habitat affecting the lives of aquatic organisms gradually. Two large dams, Xiluodu dam and Xiangjiaba dam, located right in front of the upstream reach, were planned to operate soon. These two dams would significantly change the hydrological regime and sand concentration at the downstream area, which will largely change the river habitat, for example riverbed substances. A good understanding of the river habitat, in consideration of fish, is highly required, and accordingly, efficient measures to conserve the fish diversity should be taken. 
On the other hand, the characterization of physical aspects of large rivers in recent years was restricted to parameters which were collected from the bank, from a boat, or by desktop assessment (Bain and Stevenson, 1999; Harding et al., 2009). Studies have shown that the thalweg measured from a boat was useful in describing river characteristics such as pools and riffles (Jowett, 1993; Madej, 1999; Krueger and Frothingham, 2007). The bottom acoustic backscattering characteristics have been widely used to identify or classify the seabed or riverbed properties (Burczynski, 2011). The Froude number (Fr), a hydraulic descriptor of habitat type, can also be applied to differentiate habitats (Allan and Castillo, 2007; Hauer and Lamberti, 2007; Harding et al., 2009). Therefore, in this study, a scientific echosounder and an Acoustic Doppler Current Profiler (ADCP) were tentatively used to understand the river habitat properties.

The aim of the study was to present a fast yet effective method to carry out a physical habitat survey in a non-wadeable and data-limited river reach and to conduct a quantitative assessment for realizing the physical habitat of the free-flowing stretch of the Upper Yangtze River, and to eventually contribute to developing measures for effective fish conservation.

\section{Methods}

\section{Study area}

A field survey was conducted in the Upper Yangtze River from Shuifu city, Yunnan Province (about $2 \mathrm{~km}$ downstream from Xiangjiaba Dam, rkm 1,075; river $\mathrm{km} 0$ is at Yichang, the starting point of the Upper Yangtze mileage, and Yichang is about 1669.2 $\mathrm{km}$ from the estuary) to Chongqing city (rkm 684, upper end of the Three Gorges Reservoir) (Fig. 1 and 2), covering the stretch of about $392 \mathrm{rkm}$. This river stretch passes through a mountainous area with elevations of mostly less than $500 \mathrm{~m}$ above river level ( $\mathrm{Yu}$ and $\mathrm{Lu}, 2005$ ). The river morphology within the study area is uneven and has many elevated points, central bars, and reef structures shaping the river bed, with riverbed gradients of $0.27-0.40 \%$. At the Jinsha section (Shuifu-Yibin), the river is typically $150-200 \mathrm{~m}$ wide. The river widens at the downstream of Yibin typically varying between $200-300 \mathrm{~m}$ and $600-800 \mathrm{~m}$ within and outside the gorges respectively. The maximum river width broadens at certain points to $1000-2000 \mathrm{~m}$. The average annual water level, during the period 1950-2000, at Zhutuo (rkm 806) was $200.13 \mathrm{~m}$ (daily mean range $196.21-216.31 \mathrm{~m}$ ) with the flow rate of $8520 \mathrm{~m} \cdot \mathrm{s}^{-3}$ (daily mean range 1920-53,400 m.s ${ }^{-3}$ ). Silt concentration was $1.16 \mathrm{~kg} . \mathrm{s}^{-3}$ (daily mean maximum 15.4 $\mathrm{kg} . \mathrm{s}^{-3}$ ). Building constructions took place along the river banks, and four major cities (Yibin, Luzhou, Jiangjin, and Chongqing) are located along the river (Fig. 1). Since 2005, the river reach from Shuifu to Chongqing $(385.26 \mathrm{~km}, 98.3 \%$ of the length of the study area) has been a part of the Upper Yangtze National Reserve (Fan et al., 2006). Following an international designation attributed by the United Nations Educational, Scientific and Cultural Organization (UNESCO), biosphere reserves were demarcated into three inter-related zones: core area, buffer zone, and transition area outside the buffer zone. The present study reach was designed to include these three zones (Fig. 1). Within the mainstream, there are two sections of the core area; the four buffer zones, and three transition areas (Fan et al., 2006). However, three dams, Shipeng, Zhuyangxi, and Xiaonanhai (Fig. 2) have been still planned for this river stretch (Yang et al., 2007). 


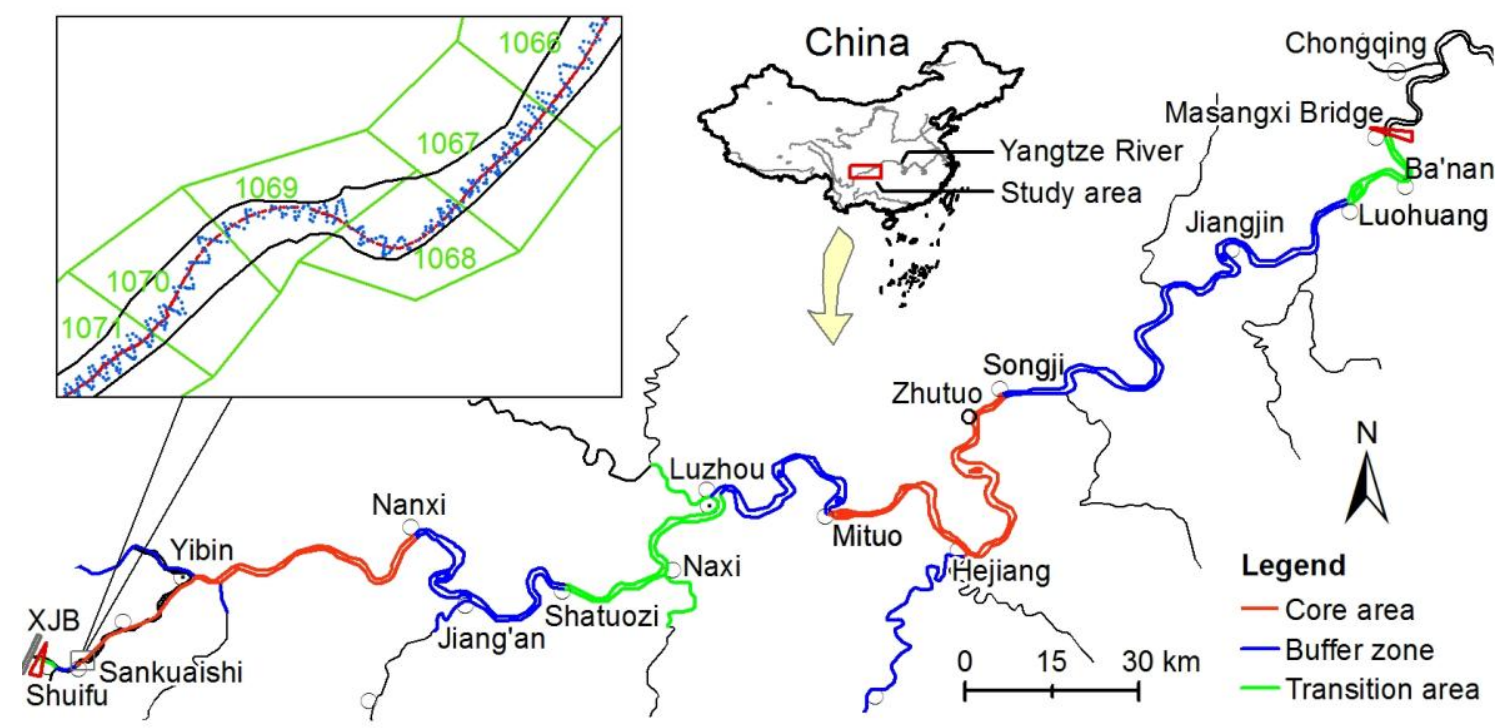

Figure 1. Study area of the upper Yangtze reach from the Xiangjiaba Dam (XJB) to the upper end of the Three Gorges Reservior (Chongqing), approximately $392 \mathrm{~km}$ river length. The two small red triangles show the start and end of the study area. The core area of the reach is displayed in red, the buffer zone in blue, and the transition area in green. In the expanded part, the zigzag line shows the survey route of the echosounder, the middle line shows the river thalweg survey route of $A D C P$, and polygons with numbers show the division by mileage

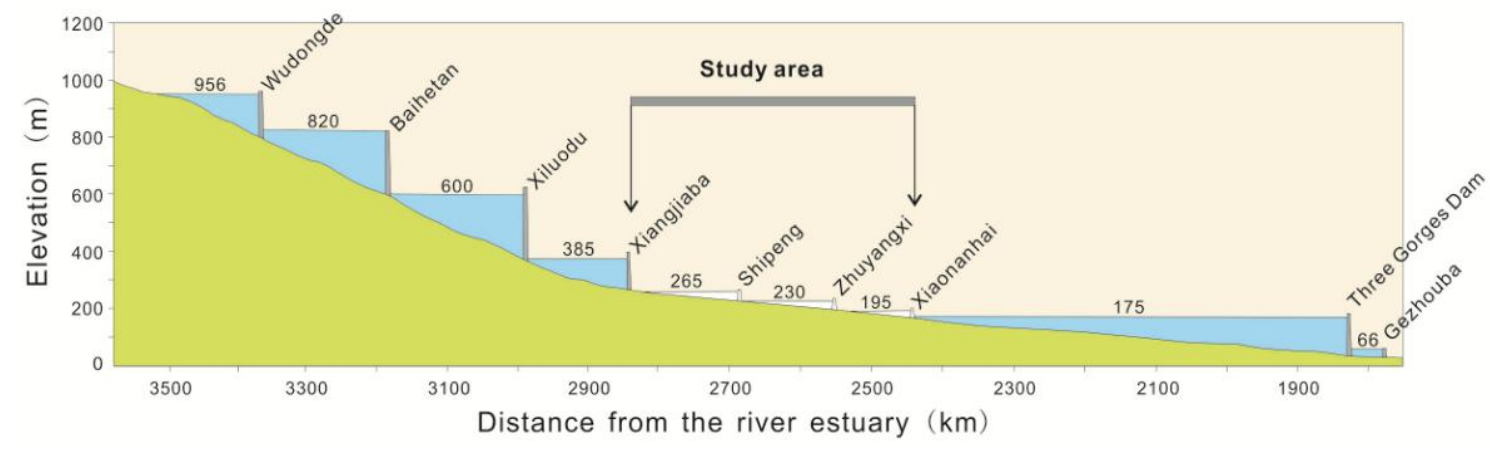

Figure 2. The sketch map showing the study area between dams, the dams of Shipeng, Zhuyangxi and Xiaonanhai which have been planned. However, there are strong concerns about whether the dams should be built, as that area will be the only free-flowing stretches in the 3,330 km of the Upper Yangtze River

\section{General workflow}

The general workflow for assessing river habitat properties using an echo sounder and an ADCP is shown in Fig. 3. In the study area, the echosounder was used for the first time to obtain the precise water depth of the river channel. A river navigation map, which is normally used by a commercial vessel for understanding approximate water depth, was integrated for designing an echosounder zigzag survey route along the river thalweg. Then the ADCP survey was conducted along the river thalweg. The water depth and river bottom acoustic scattering characteristics were acquired from the echosounder data, while the water depth and flowing characteristics (depth-averaged velocity, DAV, that is the average velocity from water surface to river bottom; Froude 
number, Fr; and Reynolds number, Re) of the river thalweg were obtained from the ADCP data.

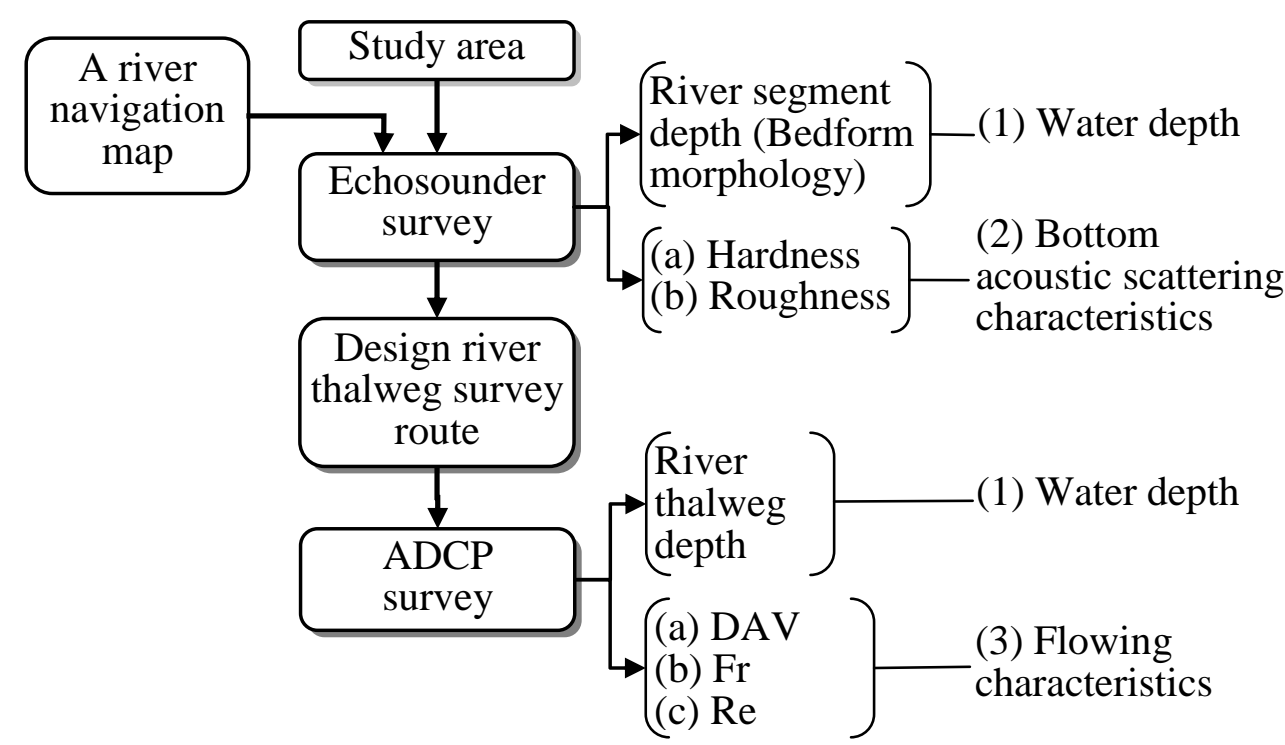

Figure 3. General workflow of the quick and efficient habitat assessment method, here the DAV is depth-averaged velocity, the Fr is Froude number, and the Re is Reynolds number

\section{Field survey}

\section{Echosounder sampling}

The echosounder survey was conducted between 29 March 2011 and 3 May 2011 in the study area. The echosounder of a $200 \mathrm{kHz}$ DT-X (BioSonics Inc., USA) equipped with a $6.8^{\circ}$ split-beam transducer was used to collect acoustic data for obtaining the precise water depth. The transducer was mounted at the front side of a $6.3 \mathrm{~m}$ long fiberglass-reinforced plastic boat equipped with an $85 \mathrm{hp}$ motor. During the operation, the rod attached to the transducer was lowered so that the sound beam started $0.5 \mathrm{~m}$ below the water surface aiming vertically downward. Sampling was set to start $1 \mathrm{~m}$ below the transducer; accordingly, the river was monitored from $1.5 \mathrm{~m}$ to the river bottom. The pulse duration was set at $0.4 \mathrm{~ms}$, the pulse rate was set to 6 pings per second, and a threshold of $-80 \mathrm{~dB}$ was applied to cut out general background noise. A GPS receiver (JRC, Japan) was attached to the echosounder for collecting the geographical positions relating to the acoustic data. The transducer source level was $220.8 \mathrm{~dB}$ re $1 \mu \mathrm{Pa}$ at $1 \mathrm{~m}$ and the receiver sensitivity was $-50.4 \mathrm{~dB}$ re $1 \mu \mathrm{Pa}$. A Dell Latitude D810 laptop running Visual Acquisition 5.0.3 software (BioSonics Inc., USA) recorded the data. The echosounder survey was conducted in zigzag transects $(\sim 200 \mathrm{~m}$ interval) at the speed of $\sim 8 \mathrm{~km} \cdot \mathrm{h}^{-1}$. The survey was conducted only during daytime since there were dangers from heavy traffic from commercial ships at night.

\section{Acoustic Doppler Current Profiler sampling}

The ADCP survey was conducted over 17 days between 24 March and 16 May, 2011. The river thalweg survey route was designed by ArcGIS 9.3 software (ESRI, USA) based on water depths from the echosounder survey and/or the river navigation map. A 600 kHz Workhorse Monitor ADCP (Teledyne RD Instruments, USA; single 
ping standard deviation $18.0 \mathrm{~cm} \cdot \mathrm{s}^{-1}$ ) was used to measure the water depth and velocity of the river thalweg. The transducer was mounted on a $19.0 \mathrm{~m}$ fiberglass-reinforced plastic boat equipped with two $205 \mathrm{~kW}$ motors. The transducer, mounted $0.55 \mathrm{~m}$ below the water surface, was aimed downward to sample data within the entire water column from $1.19 \mathrm{~m}$ below the water surface to approximately the river bottom (cell size 0.50 m). A GPS receiver (GPSMAP 60CS, Garmin, USA; accuracy: <15 m, 95\% typical) was used to navigate and produce a geographical fix for each data point. The real-time survey data of the ADCP and GPS were imported into the Dell Latitude D810 laptop, and WinRiver II software (RD Instruments, USA) was used to receive and record the data. To reduce the standard deviation of the velocity measurements, a four ping ensemble was used. During the 17 days of the survey, the average water level (data from the website of Changjiang Waterway Bureau) at Yibin, Luzhou, and Chongqing was $258.50 \pm 0.44 \mathrm{~m}$ (range $257.80-259.30 \mathrm{~m}$ ), 224.49 $\pm 0.35 \mathrm{~m}$ (range 223.85-225.00 $\mathrm{m}$ ), and $160.98 \pm 1.09 \mathrm{~m}$ (range $159.39-163.03 \mathrm{~m}$ ) respectively.

\section{Data analysis}

\section{Echosounder data analysis}

The Sonar5-Pro (Balk, 2013) was used to analyze the echosounder data for understanding water depth and bottom acoustic scattering parameters (hardness and roughness) of the zigzag sampling route. The main processing procedures conducted, using the Sonar5-Pro, included: 1) Data preparation: Data were converted to Sonar5Pro's processing format. During the conversion, the time-varied-gain 40logR was used to compensate the range dependent echoes. 2) Detecting river bottom: The Image analysis method was used to determine the bottom line with settings: bottom threshold value was $-38 \mathrm{~dB}$, pre-filter width and height both were 3 , and post-filter width and height were 5 and 1 , respectively. 3) Determining bottom acoustic scattering parameters: The first echo division method, which utilizes the ratio of the first and second parts of the first bottom echo, was used to identify the river bottom (Bakiera and Stepnowski 1996). The first part of the first bottom echo, which is the part building up from the beginning of a bottom echo to its maximum, contains the bottom hardness signature. The second part of the first bottom echo, which is the part decaying of the pulse after reaching the peak that is the maximum echo, includes the bottom roughness signature. The two backscatter parameters were exported from Sonar5-Pro and then imported into ArcGIS 9.3 for spatial distribution analysis.

\section{Acoustic Doppler Current Profiler data analysis}

The water depth and three hydraulic variables (DAV, Fr and Re) along the river thalweg were calculated using the ADCP sampled data. The water depth and flow velocity were exported as ASCII data files using the software WinRiver II (RD Instruments, 2012). These files were imported into Office Excel 2007 (Microsoft, USA) software, and a Visual Basic for Applications (VBA) script was developed to assist in the analysis. The water depth was obtained for each ADCP data point and DAV was calculated. The Fr and Re were then obtained by using the following formulae (Allan and Castillo, 2007; Hauer and Lamberti, 2007; Harding et al., 2009):

$$
\begin{aligned}
& F r=V(g D)^{-0.5} \\
& R e=V D / v
\end{aligned}
$$




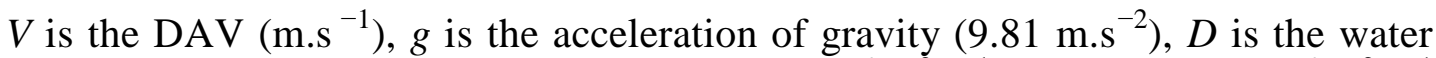
depth $(\mathrm{m})$, and $v$ is the kinematic viscosity $\left(1.3 \times 10^{-6} \mathrm{~m}^{2} \cdot \mathrm{s}^{-1}\right.$ at $10^{\circ} \mathrm{C}, 1.0 \times 10^{-6} \mathrm{~m}^{2} . \mathrm{s}^{-1}$ at $20^{\circ} \mathrm{C}$ ). The $\mathrm{Fr}$ is a dimensionless velocity-to-depth ratio and differentiates tranquil flow from broken and turbulent flow. Low Fr values are characteristics of pool habitats and higher values of riffle habitats. The Re quantifies the ratio of inertial forces of the moving fluid to the viscous properties of fluid that resists mixing. It is a dimensionless number that can distinguish types of flow and the force experienced by aquatic organisms (Allan and Castillo, 2007; Hauer and Lamberti, 2007; Harding et al., 2009).

\section{Habitat property analysis}

The river studied was divided into $1 \mathrm{~km}$ segments in accordance with the range of the waterway kilometrage used by Yangtze River navigation agencies and other organizations. A total of 392 river segments were obtained, and the statistical values (average and range) of the environmental variables in each segment were calculated by spatial analyst module in ArcGIS 9.3 (ESRI Inc., USA). Two different water depths in one segment were used in this paper. First, the "river segment depth" was defined as an average water depth in one kilometer segment obtained from the zigzag survey by the echosounder (to reduce the data amount, 1 ping out of every 100 pings was selected), and second the "river thalweg depth" was defined as an average water depth calculated from the thalweg survey by the ADCP. The Sigmaplot 12.2 (Systat Software Inc., USA) was used to profile the water depths, bottom acoustic scattering characteristics and flow characteristics along the river longitudinal direction. The three most common habitats, the pool, run, and riffle, were defined based on water depth and flow velocity along with Fr (Jowett, 1993; Krueger and Frothingham, 2007) (Table 1). K-means clustering method in SPSS 19.0 (IBM, USA) was used to identify and categorize all 392 river segments into the three habitat types.

Table 1. Definition of habitat types (Jowett, 1993; Allan and Castillo, 2007; Hauer and Lamberti, 2007; Harding et al., 2009)

\begin{tabular}{c|c}
\hline Habitat type & Definition \\
\hline Pool & Deep, slow flowing, with low Fr \\
Run & Moderate depth, flow velocity, and Fr \\
Riffle & Shallow, high flow velocity, and high Fr \\
\hline
\end{tabular}

\section{Results}

\section{Sampling efforts}

A total of 18,051 effective survey points were acquired by the echosounder, while 19,823 survey points were collected by the ADCP. When dividing the survey points by the waterway kilometrage, the average sampling number of the echosounder in each segment was $46.0 \pm 16.5$ (range 16-103), and the average sampling number of the ADCP in each segment was 50.6 \pm 12.7 (range 9-119).

\section{Water depths}

On the whole, the river thalweg depth was slightly larger than the river segment depth, however the variation tendency of two kinds of depth was consistent (Fig. 4a and 
$4 b$ ). The average river segment depth by the echosounder from the total 392 river segments was $9.5 \pm 4.9 \mathrm{~m}$ (Coefficient of Variation, $\mathrm{CV}=51.6 \%$ ) with the range of 3.2 $\mathrm{m}$ to $39.1 \mathrm{~m}$ (Fig. $4 a)$. The average river thalweg depth was $11.9 \pm 6.1 \mathrm{~m}(\mathrm{CV}=51.3 \%)$ with the range of $3.9 \mathrm{~m}$ to $42.9 \mathrm{~m}$ (Fig. $4 b$ ). The maximum water depth $(42.9 \mathrm{~m})$ was located at the site between Jiangjin and Ba'nan. The depth range of 4.0-12.0 m was the commonest depth range in the study area (Fig. 4c). In relation to the river thalweg depth in the total river segments, there were $6(1.5 \%)$ segments with depths larger than $30 \mathrm{~m}$ (rkm 706-708, 828, 839, and 957), 40 (10.2\%) segments larger than $20 \mathrm{~m}$, and 201 $(51.3 \%)$ segments larger than $10 \mathrm{~m}$.

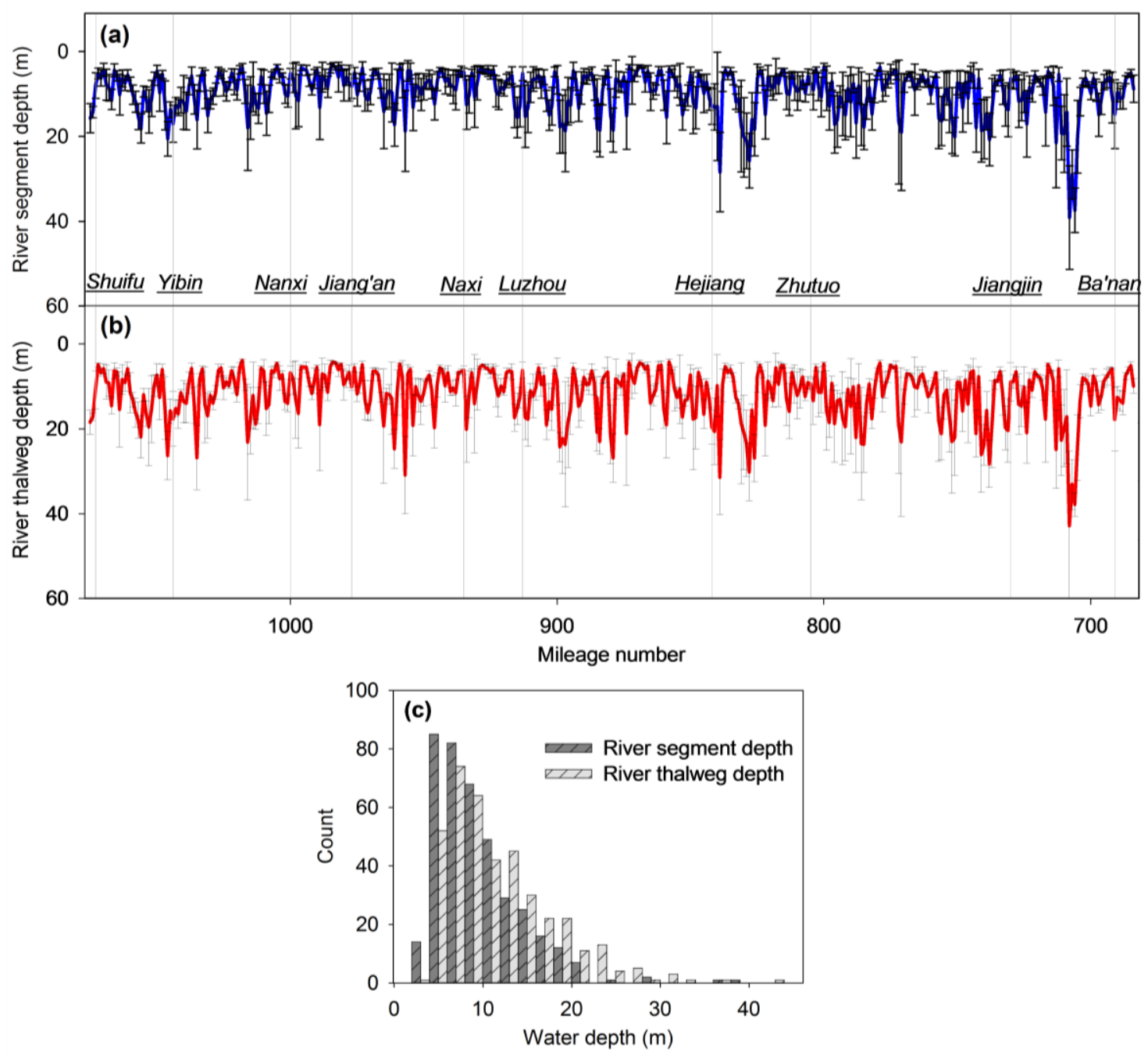

Figure 4. Water depths in the study area of the $392 \mathrm{~km}$ river reach in the Upper Yangtze River. The mileage number 0 is at Yichang and the starting point of the upper Yangtze mileage. (a) river segment depth (average water depth obtained by the zigzag survey of the echosounder), mean $\pm S . D$., (b) river thalweg depth (average water depth obtained by the thalweg survey of the $A D C P)$, mean $\pm S . D$., and (c) histogram of the two water depth values

\section{Bottom acoustic scattering characteristics}

In the entire study area, the roughness value was generally less than the hardness value, and the latter had less variation than the former (Fig. 5a and 5b). The average hardness of the 392 river segments was $-20.2 \pm 2.7 \mathrm{~dB}(\mathrm{CV}=13.4 \%)$, with the range 
being -30.1 to $-13.9 \mathrm{~dB}$ (Fig. $5 a$ ), while the average roughness was $-43.5 \pm 7.1 \mathrm{~dB}$ $(\mathrm{CV}=16.3 \%)$ with -57.2 to $-16.1 \mathrm{~dB}$ (Fig. $5 b)$. From the histograms, the hardness is slightly right skewed and the roughness is comparatively rather left skewed. The hardness in the range between -22.0 and $-18.0 \mathrm{~dB}$ occupied $56.6 \%$ of the total river segments (count> 48) (Fig. 5c). The roughness in the range from -54.0 to $-34.0 \mathrm{~dB}$ was $87.2 \%$ of 329 river segments (count> 25) (Fig. 5d). The bottom acoustic backscattering characteristic was the combination of the roughness range $(-58--30 \mathrm{~dB})$ and the hardness range $(-26--14 \mathrm{~dB})$, which implies that the hard riverbed substrate and uneven bedform morphology as the major bottom characteristics (Fig. 5e).
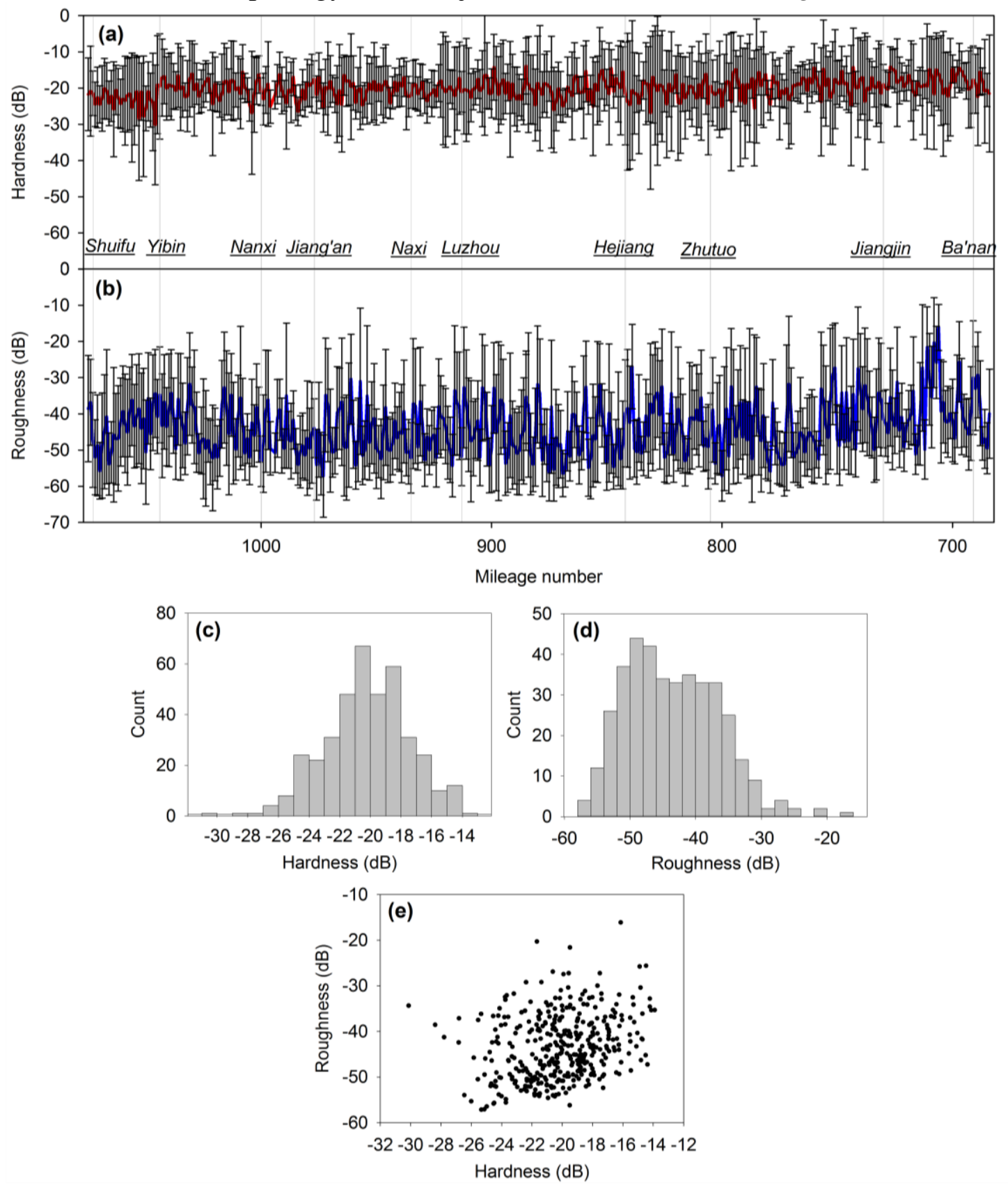

Figure 5. Bottom acoustic scattering characteristics of the $392 \mathrm{~km}$ river reach in the Upper Yangtze River. The mileage number 0 is at Yichang and the start point of the upper Yangtze mileage. (a) hardness, mean $\pm S . D$. ., (b) roughness, mean $\pm S . D$. ., (c) and (d) histograms of hardness and roughness, and (e) scattering plot of hardness and roughness 


\section{Flowing characteristics}

The three flowing variables had large variations along the longitudinal direction of the study area, which means they are highly site-specific (Fig. 6). The average DAV of the 392 river segments was $1.68 \pm 0.57 \mathrm{~m} . \mathrm{s}^{-1}(\mathrm{CV}=33.9 \%)$ with the range being $0.52-3.26 \mathrm{~m} . \mathrm{s}^{-1}$ (Fig. 6a), the lowest velocity was located at approximately $19 \mathrm{~km}$ away toward the downstream area from Luzhou (rkm 897), and the highest velocity was at approximately $10 \mathrm{~km}$ upstream from Ba'nan (rkm 701). The average Fr was $0.18 \pm 0.09$ ( $\mathrm{CV}=50.0 \%$ ) with the range being 0.03-0.38 (Fig. 6b), and the lowest and highest values were near Ba'nan (rkm 707) and Nanxi (rkm 996) respectively. The average $\operatorname{Re}$ was $1.76 \times 10^{7} \pm 7.00 \times 10^{6} \quad(\mathrm{CV}=39.8 \%)$ with the range being $6.06 \times 10^{6}-4.78 \times 10^{7}$ (Fig. 6c). The lowest and highest Re values were near Luzhou (at rkm 875 and rkm 880, respectively). From the histograms, the numerical distributions are right skewed (Fig. $6 d$, $6 e$ and $6 f$ ). The DAV in the range of $1.0-2.2{\mathrm{~m} . \mathrm{s}^{-1}}_{\text {(count }>}$ 36) (Fig. 6d), the Fr in the range of 0.06-0.28 (count>20) (Fig. 6e), and the Re in the range of $8.0 \times 10^{6}-2.6 \times 10^{7}$ (count> 21) (Fig. 6 f) occupied $70.4 \%, 79.6 \%$, and $85.5 \%$ of the total segments, respectively.
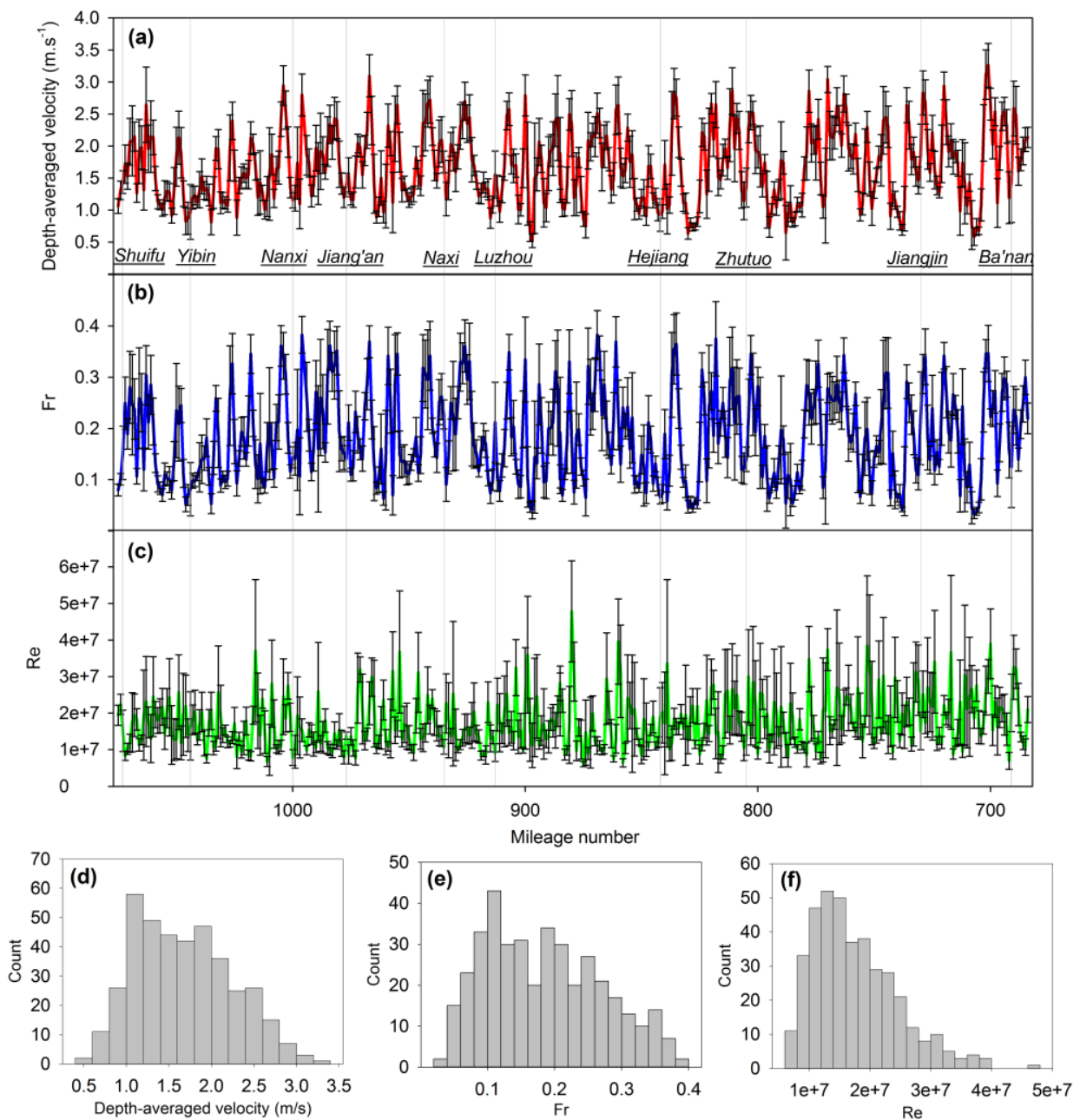

Figure 6. Flowing characteristics in the study area of the $392 \mathrm{~km}$ river reach in the upper Yangtze River, mileage number 0 is at Yichang, the start point of the upper Yangtze mileage, (a) depth-averaged velocity, mean $\pm S . D$., (b) Fr, mean $\pm S . D$., (c) Re, mean $\pm S . D .,(d)$, (e), and (f) are histogram of DAV, Fr and Re, respectively 


\section{Habitat classification}

The K-means clustering method using the parameters of the river thalweg depth, DAV, and Fr categorized the 392 river segments into the three habitat types: pool, riffle and run. As a result, the riffle was the primary habitat type, comprising $64.5 \%$ of the entire reach. The run and pool represented $30.1 \%$ and $5.4 \%$, respectively (Table 2). The spatial distribution indicated that the riffle was continuously spread, the run was intermittently distributed, and the pool was hardly seen. Yet, the pool was discretely and unevenly located throughout the study area, and in particular it was mainly distributed at the turning sections of the river channel. On the basis of visual observation, the most pool was observed near Luohuang (Fig. 7). Within the seven divided areas (Fig. 1), the component ratio of pool, run and riffle was similar in each area for example, the pool was the least, the run medium, and the riffle the most (Table 3). The buffer zone of Songji - Luohuang had the most pool segments which was nearly half of the total pool numbers, however the pool $(10.4 \%)$ in the buffer zone was still low compared to other habitat types. This buffer zone had also the most run segments (33 segments), but the highest percent of the run was at the core area of Sankuaishi - Nanxi (39.4\%). Moreover, this buffer zone occupied the most riffle segments (53 segments) although the highest percent $(84.6 \%)$ of the riffle was the transition area of Shatuozi - Tuojiang estuary. Needless to say, special care should be taken in the two core areas since they have been extremely important as unique diverse habitats.

Table 2. Clustering means, range and segment count of the three defined habitat types

\begin{tabular}{ccccc}
\hline $\begin{array}{c}\text { Habitat } \\
\text { type }\end{array}$ & $\begin{array}{c}\text { Depth } \\
\text { Average } \pm \text { S.D. } \\
\text { (Range, m) }\end{array}$ & $\begin{array}{c}\text { DAV } \\
\text { Average } \pm \text { S.D. } \\
\text { (Range, m.s } \mathbf{~}^{-1} \text { ) }\end{array}$ & $\begin{array}{c}\text { Fr } \\
\text { Average } \pm \text { S.D. } \\
\text { (Range) }\end{array}$ & Count (\%) \\
\hline \multirow{2}{*}{ Pool } & $27.79 \pm 5.11$ & $0.90 \pm 0.24$ & $0.06 \pm 0.02$ & $21(5.4)$ \\
& $(23.36-42.85)$ & $(0.52-1.57)$ & $(0.03-0.11)$ & \\
Run & $16.86 \pm 2.92$ & $1.37 \pm 0.45$ & $0.12 \pm 0.04$ & $118(30.1)$ \\
& $(12.79-23.12)$ & $(0.64-2.65)$ & $(0.05-0.25)$ & \\
Riffle & $8.23 \pm 2.34$ & $1.89 \pm 0.51$ & $0.23 \pm 0.07$ & $253(64.5)$ \\
\hline
\end{tabular}

Table 3. Segment number of the three habitat types (pool, run and riffle, Table 1 and 2) in the seven main function areas along the mainstream of the national protected area from the upstream downwards. The letters $C, B$ and $T$ signify the core area, the buffer zone, and the transition area, respectively. *Five segments within two small function areas above Sankuaishi were not included, therefore, the total number is five less than the total study segments 392

\begin{tabular}{ccccccc}
\hline Site & $\begin{array}{c}\text { River } \\
\text { mileage }\end{array}$ & $\begin{array}{c}\text { Function } \\
\text { area }\end{array}$ & $\begin{array}{c}\text { Segment } \\
\text { number }\end{array}$ & Pool (\%) & Run (\%) & Riffle (\%) \\
\hline Sankuaishi - Nanxi & $1070-1000$ & $\mathrm{C}$ & 71 & $2(2.8)$ & $28(39.4)$ & $41(57.7)$ \\
Nanxi - Shatuozi & $999-953$ & $\mathrm{~B}$ & 47 & $2(4.3)$ & $9(19.1)$ & $36(76.6)$ \\
Shatuozi - Luzhou & $952-914$ & $\mathrm{~T}$ & 39 & $0(0)$ & $6(15.4)$ & $33(84.6)$ \\
Luzhou - Mituo & $913-875$ & $\mathrm{~B}$ & 39 & $3(7.7)$ & $12(30.8)$ & $24(61.5)$ \\
Mituo - Songji & $874-800$ & $\mathrm{C}$ & 75 & $4(5.3)$ & $22(29.3)$ & $49(65.3)$ \\
Songji - Luohuang & $799-704$ & $\mathrm{~B}$ & 96 & $10(10.4)$ & $33(34.4)$ & $53(55.2)$ \\
Luohuang - & $703-684$ & $\mathrm{~T}$ & 20 & $0(0)$ & $5(25.0)$ & $15(75.0)$ \\
Masangxi Bridge & $1070-684$ & & 387 & $21(5.4)$ & $115(29.7)$ & $251(64.9)$ \\
\hline Total* & & & & & &
\end{tabular}




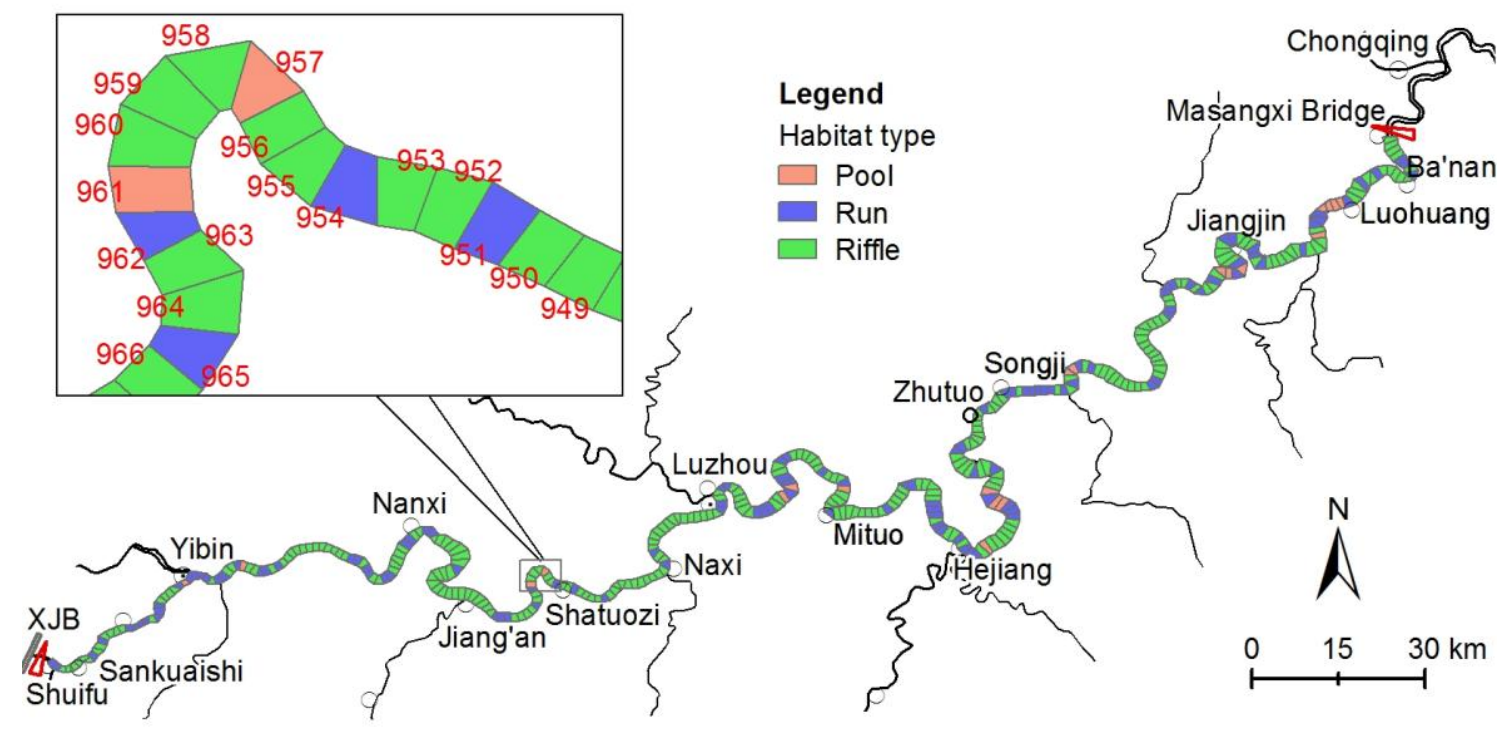

Figure 7. Habitat classification of the study area from Xiangjiaba Dam (XJB) to the upper end of the Three Gorges Reservior (Chongqing), approximately $392 \mathrm{~km}$ river length. The two small red triangles show the start and end of the study area. In the expanded part, the polygons with numbers show the division by mileage

\section{Discussion}

In this study, two common acoustic instruments on river habitat were used, which are easily transferable to other study areas. The echosounder has been used to research aquatic organism resources and/or their behaviors for many decades (Simmonds and MacLennan, 2005), and it can also be used for bathymetric or bottom classification study (Zhang et al., 2014). The ADCP is a relatively new instrument and its purpose is to measure water velocity and flow discharge. In comparison with earlier flow meters, it has significant advantages such as the availability of the non-disturbance of the flow field and the rapid provision of accurate and cost-effective results (RD instruments, 2007). As the ADCP can simultaneously measure water depth and the backscatter strength of the water volume, it is widely used in research on suspended silt (Holdaway et al., 1999), plankton biomass (Fielding et al., 2004), fish shoals (Demer et al., 2000), and riverbed substrate (Shields, 2010). Thus, this study of the usage of the two widely used acoustic instruments for assessing river physical habitat could be very referable to other similar studies.

The quick yet effective method for assessing river habitat properties has many advantages. First, it can be simply used in many unwadeable and data-limited rivers if the vessel navigation is available. Second, it has high efficiency, for example approximately $12.5 \mathrm{~km}$ of the river length can be surveyed for one day if a river width is $500 \mathrm{~m}$, a zigzag survey interval is $200 \mathrm{~m}$, a vessel speed is $8 \mathrm{~km} \cdot \mathrm{h}^{-1}$, and the working hour per day is $8 \mathrm{~h}$. Hence, it is very powerful tool even though a research area is huge. One of our final goals is to survey the entire Yangtze River main stream, that is 2713.2 $\mathrm{km}$, which is almost the cross-distance of the entire China. Third, it can provide various important ecological variables (the river thalweg depth, the Fr, and Re) which can be supportive for aquatic organism studies (Madej, 1999; Allan and Castillo, 2007; Hauer and Lamberti, 2007; Harding et al., 2009). A study indicates that both the river thalweg depth and the Fr can be used to identify habitat types such as pool, run and riffles 
(Krueger and Frothingham, 2007). Moreover, the Fr index is highly related with many life stages of the aquatic organisms (Clifford et al., 2006).

The environmental characteristics in the study area are different from those at the upper end of the lower reaches. Historically, the river flow in the upper reach of Jinsha is generally faster than the flow in the study area due to the high riverbed gradient (4.0$17.8 \%$ ). Furthermore, its highest flow velocity can be up to $10 \mathrm{~m} \cdot \mathrm{s}^{-1}$ (Yu and Lu, 2005). In the lower reach, from Chongqing to Yichang, the river channel is dominated by $\mathrm{U}$ or $\mathrm{V}$-shaped morphology, it has deeper water areas $(>50 \mathrm{~m})$, and the flow velocity is generally faster $\left(3.0-3.5 \mathrm{~m} . \mathrm{s}^{-1}\right)$ than the flow velocity in the study area (Chen et al., 2007). Currently, the upper and lower reaches have turned into reservoirs because of dam construction, and the water depth in the reaches is deeper than $100 \mathrm{~m}$, while flow velocity is less than $0.5 \mathrm{~m} . \mathrm{s}^{-1}$ (Wen, 1999; Yang et al., 2007). The assumption is that the reservoirs bottom will be dominated by thick sand while this study area is dominated by gravels (Wen, 1999; Yu and Lu, 2005; Yang et al., 2007).

Several criteria and descriptions have been proposed for identifying habitat types; these include a bed material size, a water surface slope, ranges of water depths and velocities, Fr, and descriptions of water surface characteristics (Jowett, 1993; Krueger and Frothingham, 2007). One common suggestion is that the definition of pool and riffle based on bedform morphology is reliable because it alters less with discharge than hydraulic definitions (Jowett, 1993; Krueger and Frothingham, 2007). Moreover, in bedrock and alluvial stream channels, the interval space of pool and riffle sequence is often 5-7 times of a river width (Keller and Melhorn, 1978). In this study, the definition of pool, run, and riffle were determined based on the combination of bedform (water depth) and hydraulic variables (DAV and Fr). It is envisaged that the use of this criterion will lead to better understanding of habitat characteristics for stratified sampling, and a means by which biological data can be grouped for habitat analysis.

This study provides a basic understanding of the river habitat properties in the protected area which is meaningful for future river management. However, furthermore work can be conducted to obtain more detailed habitat properties, for example the hardness and roughness values of the bottom could be classified and confirmed by the on-site video observations. Numerous studies have documented that the study area is a very important reach for many endangered, endemic, and economic fishes to spawn, rear and inhabit (Zhang et al., 2009, 2011; Jiang et al., 2010; Liu et al., 2012; Yang et al., 2012). Hence, further studies should focus on how river environments have a direct relationship with activities of aquatic organisms, how the anthropogenic activities affect their life stages, and how adverse effects can be minimized. Once more, the plan for constructing three dams in the study area should be discarded (Fig. 2). Lastly, the enhancement and improvement of the management in this study area is imperatively required, since the area seems to be the only area containing the high-biodiversity of the Upper Yangtze River.

Acknowledgements. The authors give special thanks to other members of Endangered Fishes Conservation Group of Yangtze River Fisheries Research Institute, Chinese Academy of Fishery Sciences for assisting the field work. The administrative agency of the Upper Yangtze Nature Reserve for the Rare and Endemic Fishes provided kindly help for organizing the survey team. This study was supported by the Special Scientific Research Funds for Central Non-profit Institutes, Chinese Academy of Fishery Sciences (2012A0103), and the Chinese Paddlefish rescue projects of the China Three Gorges Corporation (No. 0799524). 


\section{REFERENCES}

[1] Allan, J. D., Castillo, M. M. (2007): Stream ecology: Structure and function of running waters. 2nd edn. Springer, Dordrecht, Netherlands.

[2] Bain, M. B., Stevenson, N. J. (1999): Aquatic habitat assessment: common methods. American Fishery Society, Bethesda, Maryland.

[3] Bakiera, D., Stepnowski, A. (1996): Method of the sea bottom classification with a division of the first echo signal. - Proceedings of the XIIIth Symposium on Hydroacoustics, Gdynia-Jurata, 55-60.

[4] Balk, H. (2013): Sonar4 and Sonar5-Pro Post processing systems Operator manual version 6.0.2. Lindem Data Acquisition A/S, Oslo, Norway.

[5] Burczynski, J. (2011): Bottom Classification. BioSonics Inc., USA.

[6] Chen, Z. Y., Chen, D. C., Xu, K. Q., Zhao, Y. W., Wei, T. Y., Chen, J., Li, L. Q., Watanabe, M. (2007): Acoustic Doppler current profiler surveys along the Yangtze River. - Geomorphology 85(3-4): 155-165.

[7] Clifford, N. J., Harmar, O. P., Harvey, G., Petts, G. E. (2006): Physical habitat, ecohydraulics and river design: a review and re-evaluation of some popular concepts and methods. - Aquatic Conservation: Marine and Freshwater Ecosystems 16(4): 389-408.

[8] Demer, D. A., Barange, M., Boyd, A. J. (2000): Measurements of three-dimensional fish school velocities with an acoustic Doppler current profiler. - Fisheries Research 47(2-3): 201-214.

[9] Fan, X. G., Wei, Q. W., Chang, J. B., Rosenthal, H., He, J. X., Chen, D. Q., Shen, L., Du, H., Yang, D. G. (2006): A review on conservation issues in the upper Yangtze River - a last chance for a big challenge: Can Chinese paddlefish (Psephurus gladius), Dabry's sturgeon, (Acipenser dabryanus) and other fish species still be saved? - Journal of Applied Ichthyology 22(Suppl. 1): 32-39.

[10] Fielding, S., Griffiths, G., Roe, H. S. J. (2004): The biological validation of ADCP acoustic backscatter through direct comparison with net samples and model predictions based on acoustic-scattering models. - ICES Journal of Marine Science 61(2): 184-200.

[11] Frissell, C. A., Liss, W. J., Warren, C. E., Hurley, M. D. (1986): A Hierarchical framework for stream habitat classification: Viewing streams in a watershed context. Environmental Management 10(2): 199-214.

[12] Fu, C. Z., Wu, J. H., Chen, J. K., Wu, Q. H., Lei, G. C. (2003): Freshwater fish biodiversity in the Yangtze River basin of China: patterns, threats and conservation. Biodiversity Conservation 12(8): 1649-1685.

[13] Harding, J., Clapcott, J., Quinn, J., Hayes, J., Joy, M., Storey, R., Greig, H., Hay, J., James, T., Beech, M., Ozane, R., Meredith, A., Boothroyd, I. (2009): Stream habitat assessment protocols: for wadeable rivers and streams of New Zealand. University of Canterbury, Christchurch, New Zealand.

[14] Hauer, F. R., Lamberti, G. A. (2007): Methods in stream ecology. 2nd edn. Elsevier, Burlington, USA.

[15] Hawkins, C. P., Kershner, J. L., Bisson, P. A., Bryant, M. D., Decker, L. M., Gregory, S. V., McCullough, D. A., Overton, C. K., Reeves, G. H., Steedman, R. J., Young, M. K. (1993): A Hierarchical approach to classifying stream habitat features. - Fisheries 18(6): $3-12$.

[16] Holdaway, G. P., Thorne, P. D., Flatt, D., Jones, S. E., Prandle, D. (1999): Comparison between ADCP and transmissometer measurements of suspended sediment concentration. - Continent Shelf Research 19(3): 421-441.

[17] Jiang, W., Liu, H. Z., Duan, Z. H., Cao, W. X. (2010): Seasonal Variation in Drifting Eggs and Larvae in the Upper Yangtze, China. - Zoological Science 27(5): 402-409.

[18] Jowett, I. G. (1993): A method for objectively identifying pool, run, and riffle habitats from physical measurements. - New Zealand Journal of Marine and Freshwater Research 27(2): 241-248. 
[19] Keller, E. A., Melhorn, W. N. (1978): Rhythmic spacing and origin of pools and riffles. Geological Society of America Bulletin 89(5): 723-730.

[20] Krueger, A. M., Frothingham, K. M. (2007): Application and comparison of geomorphological and hydrological pool and riffle quantification methods. - The Geographical Bulletin 48(2): 85-95.

[21] Li, L. Q., Lu, X. X., Chen, Z. Y. (2007): River channel change during the last 50 years in the middle Yangtze River, the Jianli reach. - Geomorphology 85(3-4): 185-196.

[22] Liu, F., Wang, J., Cao, W. (2012): Long-term changes in fish assemblage following the impoundments of the Three Gorges Reservoir in Hejiang, a protected reach of the upper Yangtze River. - Knowledge and Management of Aquatic Ecosystem, 407, 06.

[23] Madej, M. A. (1999): What can thalweg profiles tell us? A case study from Redwood Creek, California. - Watershed Management Council Networker 8(4), Available at http://www.watershed.org/?q=node/286 [Accessed 18 November 2012].

[24] Müller, B., Berg, M., Yao, Z. P., Zhang, X. F., Wang, D., Pfluger, A. (2008): How polluted is the Yangtze River? Water quality downstream from the Three Gorges Dam. Science of the Total Environment 402(2-3): 232-247.

[25] RD instruments. (2007): WorkHorse Rio Grande Acoustic Doppler Current Profiler technical manual. P/N 957-6241-00.

[26] RD instruments. (2012): WinRiver II Software User's Guide. P/N 957-6231-00.

[27] Shields, F.D. Jr. (2010): Aquatic habitat bottom classification using ADCP. - Journal of Hydraulic Engineering 136(5): 336-342.

[28] Simmonds, J., MacLennan, D. (2005): Fisheries acoustics: Theory and Practice (Second edition). Blackwell Publishing, Oxford, UK.

[29] Wang, G. J., Jiang, T., Blender, R., Fraedrich, K. (2008): Yangtze 1/f discharge variability and the interacting river-lake system. - Journal of Hydrology 351(1-2): 230237.

[30] Wen, F. B. (1999): Atlas of the Changjiang River basin. China Sinomaps Press, Beijing, China.

[31] Yang, G. S., Wen, L. D., Li, L. F. (2007): Yangtze Conservation and Development Report. Changjiang Press, Wuhan, China.

[32] Yang, S. R., Gao, X., Li, M. Z., Ma, B. S., Liu, H. Z. (2012): Interannual variations of the fish assemblage in the transitional zone of the Three Gorges Reservoir: persistence and stability. - Environmental Biology of Fishes 93: 295-304.

[33] Yu, W. C., Lu, J. Y. (2005): Evolution of the Yangtze River and its Regulation. China Water Power Press, Beijing, China.

[34] Zhang, H., Wang, C. Y., Du, H., Wu, J. M., Shen, L., Wei, Q. W. (2014): Integrating hydroacoustic and optical video technologies to identify the riverbed substrate at the spawning reach of Chinese sturgeon. - Advanced Material Research 955-959: 12351240.

[35] Zhang, H., Wei, Q. W., Du, H., Li, L. X. (2011): Present status and risk for extinction of the Dabry's sturgeon (Acipenser dabryanus) in the Yangtze River watershed: a concern for intensified rehabilitation needs. - Journal of Applied Ichthyology 27(2): 181-185.

[36] Zhang, H., Wei, Q. W., Du, H., Shen, L., Li, Y. H., Zhao, Y. (2009): Is there evidence that the Chinese paddlefish (Psephurus gladius) still survives in the upper Yangtze River? Concerns inferred from hydroacoustic and capture surveys 2006-2008. - Journal of Applied Ichthyology 25(Suppl.2): 95-99.

[37] Zhang, Q., Shi, Y. F., Chen, Z. Y., Jiang, T. (2008): ADCP measured flow current of the middle-lower Changjiang River channel. - Frontiers of Earth Science in China 2(1): 1-9. 